\title{
Ensayos de alteración artificial aplicados a rocas graníticas
}

\section{Artificial weathering of granite}

\author{
T. Rivas Brea(*), B. Prieto Lamas ${ }^{(* *)}$, y $\underline{\text { B. Silva Hermo }}{ }^{(* *)}$
}

Recepción/Received: 21-VI-07

Aceptación/Accepted: 24-X-07

Publicado online/Online publishing: 12-I-08

\section{RESUMEN}

En este trabajo se hace una síntesis de varios ensayos de alteración artificial realizados con rocas graníticas. Estos ensayos tenían distintos objetivos: reproducir las formas de alteración encontradas en los edificios para llegar a conocer los mecanismos que las generan, determinar la resistencia de las diferentes rocas a la acción de las sales, evaluar la durabilidad de tratamientos de consolidación e hidrofugación y contrastar hipótesis acerca del origen de algunas sales, como el yeso, que aparecen frecuentemente en edificios graníticos. En los ensayos de cristalización de sales se utilizaron disoluciones de cloruro de sodio, sulfato de sodio, sulfato de calcio y agua de mar. Uno de estos ensayos se llevó a cabo en una cámara especialmente diseñada para reproducir la alteración por aerosol marino y otro se realizó en una cámara de $\mathrm{SO}_{2}$, con el objeto de comprobar sí en rocas graníticas se puede producir sulfatación. Se analizan los resultados obtenidos en cada ensayo y se discuten las limitaciones de los mismos para reproducir las patologías desarrolladas en los monumentos así como la influencia que pueden tener en dichas patologías aspectos como las condiciones de humectación y secado, el tipo de disolución salina y la influencia de los planos de debilidad de las rocas en el desarrollo de unas u otras ofmras de alteración.

Palabras clave: ensayos de alteración artificial, ciclos de cristalización de sales, granito, monumentos, niebla salina.

\section{SUMMARY}

This article summarizes a series of artificial weathering tests run on granite designed to: simulate the action of weathering agents on buildings and identify the underlying mechanisms, determine the salt resistance of different types of rock; evaluate consolidation and water-repellent treatment durability; and confirm hypotheses about the origin of salts such as gypsum that are often found in granite buildings. Salt crystallization tests were conducted, using sodium chloride, sodium sulphate, calcium sulphate solutions and seawater. One of these tests was conducted in a chamber specifically designed to simulate salt spray weathering and another in an $\mathrm{SO}_{2}$ chamber to ascertain whether granite is subject to sulphation. The test results are analyzed and discussed, along with the shortcomings of each type of trial as a method for simulating the decay observed in monuments. The effect of factors such as wet-dry conditions, type of saline solution and the position of the planes of weakness on the type of decay is also addressed.

Keywords: artificial weathering tests, salt crystallisation cycles, granite, monuments, saline spray.

(*) Universidad de Vigo (Vigo, España).

(**) Universidad de Santiago de Compostela (Santiago, España) 


\section{INTRODUCCIÓN}

Los ensayos de alteración artificial constituyen una metodología básica de investigación en el campo de estudio de los materiales rocosos y su alteración en los monumentos. Se trata de tests relativamente sencillos estandarizados por diversos organismos (RILEM, ASTM, DIN, NOR$M A L, U N E)$, que resultan muy útiles para comparar la susceptibilidad de diferentes rocas a la acción de un agente de alteración o para evaluar la durabilidad de tratamientos de conservación. Sin embargo, muchas veces en estos ensayos se obtienen efectos que se alejan de los encontrados en los monumentos; esto es así porque en los edificios actúan numerosos factores (ambientales y relacionados con la estructura arquitectónica) que en la simplificación de un proceso en laboratorio inevitablemente quedan excluidos. Por otra parte, el hecho de acelerar un proceso supone una modificación en sí misma.

A pesar de estas limitaciones, los ensayos de alteración constituyen una buena metodología cuando se pretende estudiar la resistencia de distintas rocas a un agente de alteración $(1,2)$, definir el proceso de deterioro $(3,4)$, comprobar qué propiedades intrínsecas de las rocas controlan dicho proceso (5-8) o evaluar la eficacia y durabilidad de tratamientos bajo condiciones lo más parecidas posible a las reales $(9,10)$. Los ensayos de alteración artificial consisten en la exposición de las rocas a ciclos de cristalización de sales, a ciclos alternantes de humectación y secado, de hielo-deshielo, a luz ultravioleta y a atmósferas contaminadas o nieblas salinas.

Los ensayos más aplicados a las rocas graníticas son los de cristalización de sales; esto se debe a que este tipo de rocas es especialmente susceptible a la acción de las sales solubles, las cuales se consideran responsables de las dos formas de alteración más graves encontradas en monumentos: la separación de las capas superficiales de los sillares (placas, plaquetas y escamas) y la desagregación arenosa o arenización (11-13).

En los ensayos de cristalización de sales estandarizados la sal más utilizada es el sulfato sódico por ser la más perniciosa y la que permite obtener de manera más rápida alteraciones visibles. Suelen desarrollarse únicamente con una sal, introduciéndola en la roca mediante inmersión parcial o total. Los procesos alternantes de cristalización-disolución o hidratación-deshidratación se intentan reproducir fijando unas condiciones de temperatura y humedad determinadas por las curvas teóricas de saturación-sobresaturación y las humedades relativas críticas para el sistema de la sal en cuestión. Como consecuencia, en ocasiones las condiciones de los ensayos se alejan de manera importante de las que definen el ambiente de un edificio en donde las temperaturas no suelen ser tan elevadas, las disoluciones alterantes suelen ser mix-

\section{INTRODUCTION}

Artificial ageing tests are routinely used to study rocks and weathering in stone monuments. These relatively simple tests, for which procedures have been laid down in RILEM, ASTM, DIN, NORMAL and UNE standards, are very useful for exploring rock susceptibility to the action of a given agent or for evaluating the durability of preservation treatments. Nonetheless, these tests often generate effects that differ substantially from what is observed in the field because many of the environmental and structural factors present in actual monuments are inevitably neglected in simplified laboratory procedures. Moreover, the mere acceleration of weathering or ageing is in itself a modification.

Despite these limitations, weathering tests are useful for studying the resistance of a particular type of rock to weathering agents $(1,2)$, defining decay processes (3, $4)$, identifying the intrinsic properties that condition weathering (5-8) and evaluating treatment effectiveness and durability under conditions that simulate real situations as accurately as possible $(9,10)$. Artificial weathering tests usually consist in exposing rocks to salt crystallisation cycles, wet-dry cycles, freeze-thaw cycles, ultraviolet light, polluted atmospheres and salt spray.

Salt crystallisation tests are used primarily to test granite, a rock particularly vulnerable to the action of soluble salts. These agents are responsible for the two most severe forms of deterioration in monuments, namely, superficial detachments of ashlars (plaques, plaquettes and scales) and granular disaggregation (11-13).

Standard salt crystallisation tests typically use sodium sulphate because it is the most harmful salt, generating visible signs of alteration more rapidly than other salts. The test usually consists in immersing the rock wholly or partially in a solution containing a single salt. Alternating crystallisation-dissolution and hydration-dehydration processes are reproduced by fixing specific temperature and humidity conditions established on the grounds of the theoretical saturation-oversaturation curves and the critical relative humidity for each salt system. Consequently, test conditions often differ substantially from the actual environment affecting buildings, where, for example, the temperature may be lower, the weathering salts are usually mixed and found at lower concentrations and the time that rock and solution are in contact is generally 
tas y poco concentradas y los tiempos de contacto rocadisolución no suelen ser tan prolongados. Así, algunos autores han desarrollado procedimientos alternativos con el objetivo de reproducir de manera más realista las condiciones ambientales que afectan a los edificios (14-17).

Algunos de estos aspectos se discuten en el presente trabajo, en el que se presenta una síntesis de los resultados de diversos ensayos de alteración artificial llevados a cabo sobre rocas graníticas en Galicia. Los ensayos fueron diseñados persiguiendo distintos objetivos: reproducir las formas de alteración encontradas en los edificios para llegar a conocer los mecanismos que las generan, determinar la resistencia de las diferentes rocas a la acción de las sales, evaluar la durabilidad de tratamientos de consolidación e hidrofugación, y constatar hipótesis acerca del origen de algunas sales, como el yeso, que aparecen frecuentemente en edificios graníticos.

\section{MATERIAL Y MÉTODOS}

Los ensayos que se describen en este trabajo (Tabla 1) fueron realizados sobre diferentes granitos que afloran en el NW peninsular y que han sido utilizados antiguamente y en la actualidad en la construcción de edificios de interés histórico-artístico y arqueológico en Galicia. Se trata en su mayoría de granitos alcalinos de dos micas cuya génesis está ligada a la Orogenia Hercínica y por tanto aparecen en afloramiento muy tectonizados, deformados, más o menos orientados, con frecuentes heterogeneidades. La porosidad abierta o accesible al agua (PA) de las rocas utilizadas oscila entre el $5 \%$ y el $0,9 \%$ (la única roca de las ensayadas que se caracterizó como una granodiorita).

Previamente a los ensayos las rocas se caracterizaron desde el punto de vista químico (\% de elementos mayoritarios por fluorescencia de rayos $\mathrm{X}$ ), mineralógico (difracción de rayos $\mathrm{X}$ ) y petrográfico mediante el estudio de láminas delgadas con microscopio petrográfico y con microscopio de fluorescencia para visualizar las fisuras (añadiendo un fluorocromo a la resina de impregnación). También se estudió su comportamiento físico y mecánico determinando una serie de parámetros y propiedades (18) tales como porosidad accesible, distribución de tamaños de poros (porosimetría de inyección de $\mathrm{Hg}$ ), absorción de agua, cinéticas de absorción-desorción, capilaridad, permeabilidad al vapor, color, carácter hidrófugo de las superficies y resistencia mecánica a compresión y a flexotracción.

Algunas de estas propiedades se determinaron antes y después de los ensayos pues sirven para evaluar las alteraciones producidas por los mismos. La determinación de unas u otras dependió del objetivo del ensayo. Así, por ejemplo, si los ensayos de alteración se utilizan para eva- shorter. Consequently, some authors have developed alternative procedures that simulate environmental conditions more realistically (14-17).

Some of the above questions are addressed in the present paper, which describes the results of artificial weathering tests conducted on granite from Galicia, Spain. The tests were designed to meet a number of objectives: to simulate weathering on buildings and identify the underlying mechanisms; to determine the salt resistance of different types of rocks: to evaluate consolidation and water-repellent treatment durability; and to confirm hypotheses about the origin of salts such as gypsum that are often found in granite buildings.

\section{MATERIALS AND METHODS}

The artificial weathering tests described in this article (summarized in Table 1) were conducted on granite from Galicia (northwestern Spain), where this stone has traditionally been used to erect buildings of historicartistic or archaeological interest. The rock used was mostly alkaline, two-mica granite associated with the Hercynian orogeny. The outcrops of such stone are highly tectonized, deformed, more or less oriented and frequently uneven. The open or water-accessible porosity $(O P)$ of the rocks used ranged from $5 \%$ to $0.9 \%$ (the latter figure found for the sole rock tested that was characterized as granodiorite).

Prior to testing, the rocks were characterized chemically ( $\%$ of main elements), using $X$-ray fluorescence; mineralogically, via X-ray diffraction; and petrographically, by analyzing thin sections first under a petrographic and then under a fluorescence microscope to detect cracks visible after fluorochrome was added to the impregnation resin. Mechanical and physical behaviour was determined from parameters and properties (18) such as open porosity and pore size distribution (found with mercury intrusion porosimetry), water absorption, absorption-desorption kinetics, capillarity, water vapour permeability, colour, surface water repellence and compressive and bending strength.

Some of these properties were studied both before and after the tests to assess the degree of deterioration generated. The type of property determined depended on the aim sought with the test. Thus, for instance, ageing tests designed to evaluate a water repellent treatment would 
luar un tratamiento de hidrofugación, no tiene sentido determinar la porosidad accesible y sí el carácter hidrófugo de las superficies tratadas (antes y después de los ensayos) y las variaciones de color.

Un aspecto analizado en algunos de los ensayos es la influencia en los procesos de alteración de los planos de debilidad de las rocas (en el caso de los granitos, el denominado andar de la piedra y los planos de descompresión del macizo). Dichos planos condicionan significativamente el comportamiento de las rocas frente a procesos direccionales, como el transporte de vapor de agua o la resistencia a compresión y flexotracción (19-20). En algunos ensayos la entrada de las disoluciones salinas y su evaporación se forzó en una dirección, intentando emular lo que ocurre en los muros de un edificio, en donde la humectación y el secado tienen lugar fundamentalmente por la cara expuesta de los sillares. De esta manera, es posible estudiar la influencia de estos planos de debilidad en la resistencia a los ciclos o en las patologías generadas.

\section{RESULTADOS Y DISCUSIÓN}

Los tres primeros ensayos (test 1, 2 y 3), descritos sintéticamente en la Tabla 1, se hicieron con sulfato de sodio al $14 \%$. El primero de ellos está basado en la norma RILEM (18) y se realizó con el objetivo de comparar la resistencia de las distintas rocas a la sal. El segundo ensayo (test 2) es una modificación del primero en lo que respecta a la manera en que la disolución salina penetra en las rocas. Así, impermeabilizando las caras laterales de las probetas, la entrada de la disolución se efectúa por una cara y la evaporación de la misma se fuerza por la cara opuesta, intentando de esta manera simular lo que ocurre en un muro. En el tercer ensayo (test 3) se utilizaron probetas más grandes que las especificadas por la norma y con tres de sus seis caras abujardadas; el objetivo fue comprobar si el trabajado superficial incrementa la alterabilidad de las rocas.

En estos tres ensayos, se constató que las rocas más susceptibles al deterioro fueron las más porosas (que perdieron más peso durante el ensayo), aunque se observó cierta influencia del tamaño de grano, de manera que la granodiorita de grano grueso de $0,9 \%$ de porosidad mostró la misma susceptibilidad que un granito de dos micas de grano fino de 2,8\% de porosidad. Las morfologías de deterioro que se desarrollaron fueron distintas en cada uno de los ensayos. En el primero, que fue el más agresivo, las rocas desarrollaron fuerte desagregación arenosa y formación de eflorescencias. En el ensayo de evaporación forzada se desarrollaron tanto arenización como descamaciones y siempre en la cara de evaporación. Por microscopía óptica de fluorescencia se puso en evidencia que las descamaciones son consecuencia de la aparición include the assessment of water repellence on the treated surface (before and after the test) as well as colour variations, but not open porosity.

One aspect analyzed in some of the tests was the effect of the planes of weakness of the rock (i.e., in granite the cleavage and bedding planes) on deterioration processes. These planes significantly affect the behaviour of rocks in directional processes such as water vapour transport or compressive and bending strength (19-20). In some tests, salt solution absorption and evaporation were restricted to a single direction only in an attempt to simulate events as they occur in building walls, where wetting and drying mainly affect the exposed face of the ashlars. Such tests constituted the basis for a study of how planes of weakness impact salt resistance and the type of pathology observed.

\section{RESULTS AND DISCUSSION}

The first three tests (1, 2 and 3), all performed with 14\% sodium sulphate solution, are schematically described in Table 1. The aim of the first, based on the RILEM standard (18), was to compare the salt resistance of the various rocks. The second test also followed the RILEM procedure, but varying the saline solution uptake in the rocks. Here, the lateral faces of the specimens were water-proofed to ensure that absorption occurred on one face only and evaporation on the opposite face, to simulate the conditions prevailing in real walls. In the third test, the specimens were larger than specified in the standard and three of the six sides were bush-hammered to ascertain whether surface finishes varied rock vulnerability to weathering.

The results of these three tests showed that while the most porous rocks were the ones most susceptible to decay (exhibiting the greatest weight loss), grain size was likewise relevant. Thick-grained granodiorite, with $0.9 \%$ porosity, proved to be as susceptible as a fine grained two-mica granite with $2.8 \%$ porosity. Decay morphology varied in the different tests. In the first test, the most aggressive of the three, the rock showed substantial granular disaggregation and efflorescence. Granular disaggregation and scaling were observed on the evaporation face in the second test (guided evaporation). Optical fluorescence microscopy revealed that scaling was a result of cracking parallel to the evaporation surface and both parallel and perpendicular to the planes of weakness (cleavage or bedding planes), an indication 


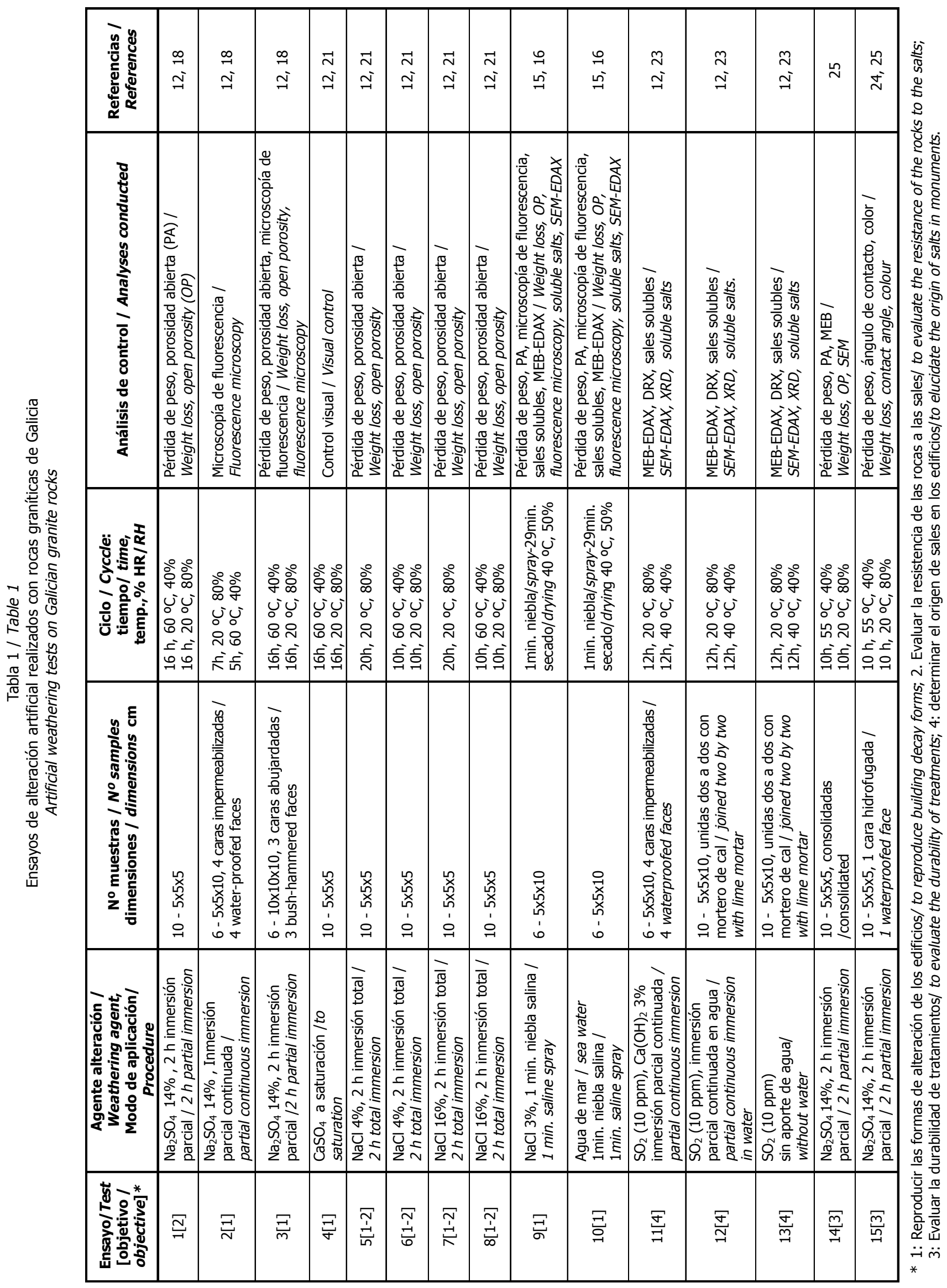


de fisuras paralelas a la superficie de evaporación; dichas fisuras se formaron tanto paralelamente a los planos del andar como perpendicularmente a ellos. Esto demuestra que el desencadenante de la descamación es la cristalización de sales por debajo de la superficie de evaporación y que es independiente de la dirección del andar, si bien cuando éste es paralelo a la superficie lógicamente el proceso de descamación está facilitado $(12,13)$.

En las probetas abujardadas (test 3) se desarrolló arenización, acompañada de una intensa formación de eflorescencias, y escamas tanto paralelamente como perpendicularmente a la dirección del andar e independientemente de si la cara estaba abujardada o no. En consecuencia, este ensayo no permitió comprobar una mayor susceptibilidad al deterioro de las superficies trabajadas como en principio se esperaba, a pesar de que mediante microscopia de fluorescencia se constató en estas caras abujardadas la aparición de fisuras transgranulares hasta una profundidad entre 1,5-2,0 $\mathrm{mm}$ (12).

En estos tres ensayos, sobre todo en el primero y el tercero, la arenización generada presentó un aspecto y una intensidad tal que pocas veces se ha visto en los edificios graníticos; asimismo la formación de eflorescencias es algo muy raro en los paramentos exteriores de los edificios gallegos. Por otra parte, los estudios realizados en edificios (13) revelan que las patologías asociadas a los sulfatos son las separaciones superficiales, no la arenización que sí se produjo en estos ensayos. Por todo ello, y con el propósito de reproducir de manera más fiel las patologías reales, se sometieron estos mismos granitos al ensayo basado en la norma RILEM pero utilizando sulfato de calcio (ensayo no 4, Tabla1), sal encontrada en elevadas cantidades en muestras de placas y plaquetas de edificios graníticos (13). Este ensayo, sin embargo, no dio resultados satisfactorios en cuanto a que no se desarrolló ninguna patología salvo la formación de eflorescencias.

Los siguientes ciclos (tests 5, 6, 7 y 8) se llevaron a cabo con cloruro sódico (21) y su objetivo era analizar las condiciones que determinan el proceso de desagregación arenosa, que en los edificios graníticos gallegos suele ir asociada a la presencia de esta sal (13). Se comprobó que con $\mathrm{NaCl}$ al $16 \%$ se producía más arenización que con $\mathrm{NaCl}$ al $4 \%$ y que el deterioro era más intenso cuando el secado se producía a mayor temperatura. Las rocas más porosas fueron las que más se desagregaron manifestando redondeamiento de las aristas y pérdida de masa, así como abundantes eflorescencias. El deterioro provocado en laboratorio por el cloruro sódico sobre los granitos resultó ser relativamente poco importante a pesar de que a sus efectos se atribuyen las espectaculares morfologías de alteración que se encuentran en algunos monumentos costeros. that it was triggered by salt crystallisation beneath the evaporation surface and independent of the position of the planes of weakness. Nonetheless, earlier studies showed that scaling is more likely when the planes of weakness are parallel to the evaporation face $(12,13)$.

After the third test, granular disaggregation was observed in the bush-hammered specimens, along with considerable efflorescence and scaling; the latter appeared both parallel and perpendicular to the planes of weakness and regardless of the type of surface finish. Contrary to what was initially expected, then, this test did not confirm that bush-hammering increased stone susceptibility, even though previous fluorescence microscopy had revealed trans-granular cracking to depths of 1.5 to $2.0 \mathrm{~mm}$ (12).

The appearance and intensity of the granular disaggregation observed in the stone, particularly after the first and third tests, are seldom seen in granite buildings. Efflorescence is likewise unusual in exposed stone walls in Galicia. Moreover, prior building surveys (13) revealed that sulphate-induced pathologies consist in surface detachment and involve no granular disaggregation. In light of the foregoing, with a view to reproducing actual pathologies more accurately, the same granite was subject to a RILEM-based test (Test 4 in Table 1) with calcium sulphate, large quantities of which have been found in plaques and plaquetes on granite buildings (13). The results of this test were unsatisfactory, however, for the only pathology observed was efflorescence.

In the following battery of tests $(5,6,7$ and 8), conducted with sodium chloride (21), the aim was to analyze the conditions that determine granular disaggregation, a process typically associated in Galicia with the presence of this salt in granite buildings (13). Granular disaggregation was observed in all four tests and found to be more intense using $16 \%$ than using $4 \% \mathrm{NaCl}$ solutions. Decay, in turn, advanced more rapidly at higher drying temperatures. Granular disaggregation was most intense in the rocks with higher porosity, which exhibited rounding of edges, loss of mass and considerable efflorescence. In laboratory tests, sodium chloride failed to cause significant granite deterioration, even though the dramatic effects of weathering observed in some coastal monuments are attributed to this salt. 
La entrada de las sales en los edificios, especialmente las de origen marino, es generalmente a través de las paredes expuestas y en forma de aerosoles; el viento también ejerce un papel activo en la alteración acelerando la evaporación y la caída de los granos. Teniendo en cuenta estos hechos, el ensayo número 9 se desarrolló bajo unas condiciones más fieles a las reales: el cloruro de sodio (en concentración similar a la del agua de mar) se aplicó en forma de niebla durante un minuto, continuando con 29 minutos de secado mediante ventilación forzada; de este modo se llevaban a cabo 48 ciclos al día (16). En estas condiciones la arenización que se desarrolló presentaba un aspecto similar a la observada en los edificios, siendo las eflorescencias escasas. El ensayo número 10 realizado en las mismas condiciones pero con agua de mar (22) produjo unos resultados que se aproximan todavía más a la realidad: no sólo el aspecto de las arenizaciones (en una roca se produjo, por ejemplo, un principio de alveolización), sino que las variaciones en profundidad del contenido de iones solubles (a escala milimétrica pero también micrométrica mediante el análisis con la microsonda de fluorescencia de rayos $X, E D A X$ ) (Figura 1) son fiel reflejo de los obtenidos en los monumentos afectados por este tipo de alteración. Estos ensayos permitieron constatar cuan diferente puede ser el mecanismo de deterioro cuando se usa una disolución salina simple y cuando se usa una disolución mixta.
The salts (particularly marine salts) responsible for granular disaggregation penetrate the exposed face of stone facades in the form of spray, while wind action furthers this type of decay by favouring evaporation and grain detachment. Test number 9, in which all these considerations were taken into account, resembled such real conditions more closely than the preceding trials. A sodium chloride solution at a concentration similar to that found in sea water was sprayed on to the specimens 48 times a day for one-minute intervals, followed by 29 minutes of forced ventilation drying (16). The granular disaggregation resulting from this test was similar to the decay observed in buildings and accompanied by scant efflorescence. Test number 10, conducted under the same conditions but with sea water (22), yielded results even closer to field observations. Not only the macroappearance of granular disaggregation (incipient alveolar weathering was observed in one sample, for instance), but also the variations in soluble ion content with depth (milli- and micrometrically, based on energy dispersive spectroscopy, EDAX, Figure 1) bore a close resemblance to the findings for samples taken from buildings exposed to such weathering. These results stand as evidence that decay mechanisms vary substantially depending on whether they are triggered by simple or mixed saline solutions.

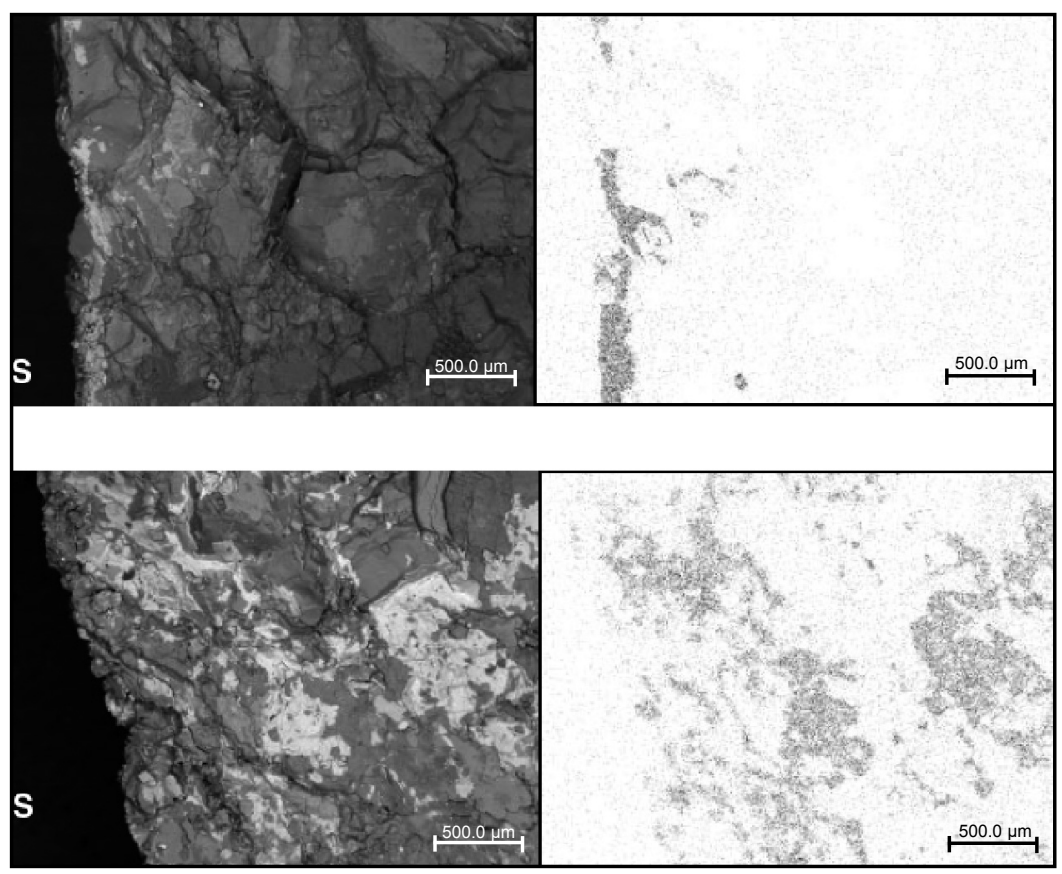

Figura 1. Mapas de distribución de cloro (obtenidos con la microsonda de fluorescencia de rayos $\mathrm{x}$ acoplada al $\mathrm{MEB}$ ) en secciones de probetas graníticas sometidas al ensayo de niebla salina con $\mathrm{NaCl}$ (arriba) y agua de mar (abajo). S indica la superficie de la probeta sobre la que se aplicó el spray. (22)

Figure 1. Maps of chlorine distribution (obtained using a fluorescence $x$-ray microprobe coupled to the SEM) in sections of granite samples tested with $\mathrm{NaCl}$ spray (up) and sea water spray (down). $\mathrm{S}$ is the exposed surface where spray was applied. (22) 
Los ensayos $n^{0} 11,12$ y 13 se diseñaron con el objeto de comprobar si uno de los orígenes del yeso que frecuentemente aparece en los monumentos de Santiago de Compostela (13) podría ser la sulfatación del granito, siempre que haya un aporte adicional de calcio, dada la escasez de este elemento en las rocas graníticas. En una cámara de $\mathrm{SO}_{2}$ con una concentración de gas similar a la registrada en la ciudad de Santiago (23) se trataron probetas de granito a las que se suministró calcio de dos maneras diferentes. En el ensayo n ${ }^{0} 11$ el calcio se aportó mediante una disolución de $\mathrm{Ca}(\mathrm{OH})_{2}$ que las rocas absorbieron por capilaridad. En los otros dos ensayos el calcio se liberó a partir de una argamasa de cal con la que se unieron las probetas dos a dos; en el ensayo no 12 las probetas se mantuvieron húmedas absorbiendo agua por capilaridad de forma continua, mientras que en el no 13 las probetas permanecieron secas, sin aporte de agua líquida, sometidas a las condiciones de humedad existentes dentro de la cámara (Tabla1).
Tests 11, 12 and 13 were designed to verify whether, in the presence of other sources of calcium given the scarcity of this element in granite, the origin of the gypsum frequently found on the monuments at Santiago de Compostela (13) might be granite sulphation (among others). Granite specimens were placed in an $\mathrm{SO}_{2}$ chamber with the gas at the concentration prevailing in that city (23) and two sources of additional calcium: in test 11 , calcium was supplied in the form of a $\mathrm{Ca}(\mathrm{OH})_{2}$ solution, absorbed by the rock by capillarity. In the other two tests, the calcium was released by a lime mortar used to join the granite specimens in groups of two. Wet specimens (which absorbed water by capillarity) were used in test 12, while in test 13 no additional source of water was supplied (Table 1).
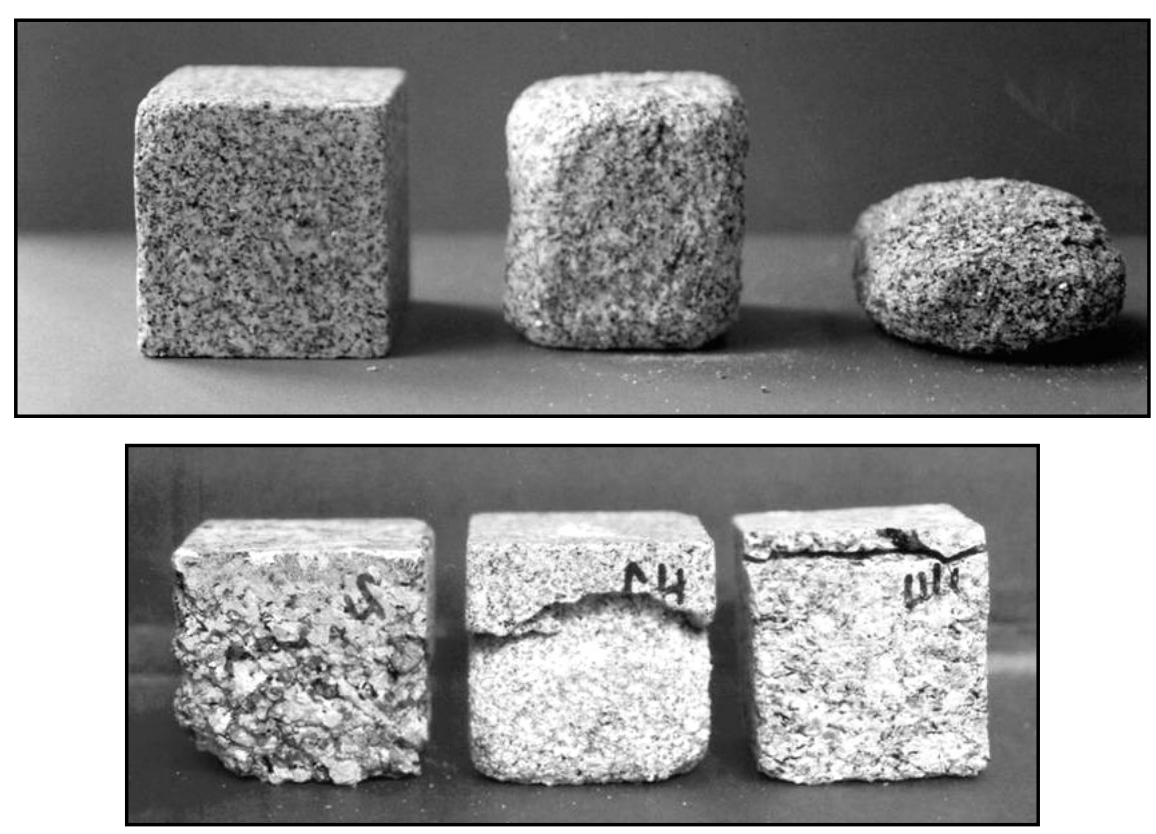

Figura 2. Aspecto de probetas graníticas tratadas con consolidante (arriba) e hidrofugante (abajo) y sometidas a 60 ciclos de alteración artificial con sulfato de sodio según RILEM (1978). En la imagen superior y de izquierda a derecha: probeta control (sin consolidar y sin alterar), probeta consolidada alterada artificialmente y probeta sin consolidar alterada artificialmente. En la imagen inferior: probetas de tres granitos distintos hidrofugadas y alteradas artificialmente (24).

Figure 2. Appearance of specimens treated with consolidants (up) and water repellents (donw) and subjected to 60 cycles with sodium sulphate (RILEM 1978). Upper photo, left to right: control specimen (not consolidated and not subjected to ageing test), consolidated specimen subjected to artificial weathering and non-consolidated specimen subjected to artifical weathering. Lower photo: specimens of three different granites treated with water repellent product and subjected to the salt test. (24).

En las probetas unidas con mortero aparecieron de manera muy rápida eflorescencias de yeso. Esta sal se detectó también en el interior de la masa rocosa, por difracción de rayos $X(D R X)$, por microscopía electrónica de barrido (MEB) y por análisis químico, y la cantidad detectada fue mayor en las probetas que se mantuvieron
Gypsum efflorescence appeared very early in the mortared granite specimens. This salt was also detected inside the rock mass the $X$-ray diffraction (XRD), scanning electron microscopy (SEM) and chemical analyses, in greater amounts in the wet specimens. Gypsum likewise formed on the mortar joints, in this case more profusely in the 
humedas. También se formó yeso sobre los morteros de las juntas, en este caso en mayor cantidad en las probetas a las que no se aportó agua. Estos resultados demostraron que la sulfatación de los morteros de cal ocurre de manera bastante rápida incluso con bajas concentraciones de $\mathrm{SO}_{2}$ y que el yeso formado puede ser solubilizado e introducido en la roca desde las juntas o revestimientos. Las probetas a las que se aportó el calcio mediante absorción capilar de $\mathrm{Ca}(\mathrm{OH})_{2}$ también mostraron eflorescencias pero en este caso de sulfato sódico; este hecho se puede explicar por la posible liberación de iones $\mathrm{Na}^{+}$ de los feldespatos por interacción con la disolución utilizada, fuertemente alcalina y corrosiva.

Por último, en la Tabla 1 se exponen dos ensayos de cristalización de sales (tests 14 y 15 ) realizados con el objetivo de evaluar la durabilidad de tratamientos de consolidación y de hidrofugación aplicados sobre granitos (24, 25). El ensayo con sulfato de sodio basado en la norma RILEM fue muy eficaz para identificar el consolidante que mejoró en mayor medida la coherencia de las rocas. En el caso de las muestras hidrofugadas, al final del ensayo se produjo la total separación de la capa superficial tratada (Figura 2) revelando la importancia de que no existan fuentes activas de sales en paramentos que van a ser tratados, pues, en caso contrario, el tratamiento puede resultar absolutamente contraproducente.

\section{CONCLUSIONES}

Los resultados de la comparación de los diferentes tests presentados en este trabajo permiten deducir lo siguiente:

- En términos generales los tests permiten alcanzar los objetivos fijados en cada caso: los tests más sencillos, que son aquellos que usan disoluciones salinas simples de concentración moderada-alta y unas condiciones de secado a elevadas temperaturas, permiten de manera rápida y eficaz determinar la resistencia de cada roca frente a la acción de las sales. Se demostró que las rocas más resistentes fueron las menos porosas y las de grano más fino. Estos tests son también muy útiles para evaluar la durabilidad de tratamientos de conservación. Comparando los efectos de las distintas sales, lo más destacable es la baja intensidad de deterioro que provoca el cloruro de sodio en laboratorio, en contraposición a los efectos devastadores que produce en los edificios.

- Cuando el objetivo es definir las condiciones que dan lugar a las patologías observadas en los edificios, es necesario modificar los tests tanto en lo que se refiere al tipo y concentración de la sal como en el modo de aplicación de las disoluciones y las temperaturas de secado. Los tests que han dado resultados más satis- dry specimens. These results inferred that lime mortar sulphation takes place fairly rapidly even at low $\mathrm{SO}_{2}$ concentrations and that the gypsum formed in the joints or on the plasters may dissolve and penetrate the rock. The specimens absorbing calcium in the form of $\mathrm{Ca}(\mathrm{OH})_{2}$ likewise exhibited efflorescence, which in this case consisted in sodium sulphate, perhaps as a result of the $\mathrm{Na}^{+}$ions released in the interaction between feldspar and the highly alcaline and corrosive solution used.

Lastly, Table 1 lists the salt crystallization tests (14 and 15) conducted to assess the durability of the consolidation and water repellent treatments applied to the granite $(24,25)$. The sodium sulphate test based on the RILEM standard very effectively identified the consolidating substance that best improved rock cohesion the most. The waterprooted layer, became wholly detached by the end of the test (Figure 2), an indication of the importance of the absence of active sources of salt on surfaces to be treated, for otherwise the treatment may be completely counter-productive.

\section{CONCLUSIONS}

The conclusions that may be drawn from the comparison of the results of the tests summarized in this study are:

- Generally speaking, the stated aim sought in all the tests was reached: the simplest, consisting in rock exposure to moderate-high concentrations of a single salt followed by high temperature drying provided a speedy and effective measure of rock resistance to salt action. The stone with the lowest porosity and finest grain proved to be the most resistant. These tests are also very useful to assess preservation treatment durability. The most prominent finding was the scant deterioration prompted by sodium chloride in laboratory tests, compared to the devastating effects of this salt on buildings.

- To determine the conditions giving rise to the pathologies observed in buildings, the tests had to be modified in terms of salt type and concentration, application procedure and drying temperature. Brief spraying with mixed solutions followed by moderate temperature drying were the test conditions that provided the 
factorios a la hora de reproducir las patologías de los edificios, fueron aquellos realizados con disoluciones mixtas, aplicando las disoluciones en pequeños episodios de spray y secando a temperatura suave. En contrapartida, estos test tienen el inconveniente de ser más difícilmente reproducibles.

- Resulta muy útil la versatilidad que ofrecen los tests de alteración artificial para variar las condiciones de trabajo; en este sentido, los ensayos en cámara de $\mathrm{SO}_{2}$, en los que se expusieron materiales combinados (piedra y mortero) bajo condiciones de humectación variadas, han permitido determinar un posible origen del yeso presente en edificios graníticos urbanos gallegos.

- Por último, la comparación entre los distintos ensayos también permite comprobar la utilidad de las distintas técnicas de control de los cambios durante los mismos. La determinación de la porosidad accesible al agua, por ejemplo, es poco recomendable, al interferir en su determinación la presencia de sales en los poros. Por el contrario, la microscopía óptica de fluorescencia se revela como una técnica muy útil para analizar los cambios en la fisuración de las rocas provocados por las sales. truest simulation of actual building pathologies. The drawback to such tests, however, is that they are difficult to reproduce.
- In the present study, working conditions could be readily varied thanks to the versatility of artificial weathering tests. The $\mathrm{SO}_{2}$ chamber tests, for instance, in which combinations of stone and mortar were exposed to the gas under different wetting conditions, revealed a possible source of the gypsum observed on urban granite buildings in Galicia.

- Lastly, a comparison of the results of the thirteen tests also denoted the utility of the different techniques for controlling change during the trials. Determining open porosity for instance, is not recommended because the presence of salts in pores interferes in the determination. Optical fluorescence microscopy, by contrast, proved to be a very useful technique for analyzing changes in rock fissures caused by salts.

\section{BIBLIOGRAFÍA / BIBLIOGRAPHY}

(1) Ordaz, J., Esbert. R.: "Porosity and capillarity in some sandstones and dolomite monumental stones." Proceed. V Int. Symp. On Deterioration and Conservation of Stone, Lausanne (1985), vol. 1, pp. 93-102.

(2) Smith, B. J., McGreevy, J. P.: "Contour scaling of a sandstone by salt weathering under simulated hot desert conditions". Earth Surface Processes and landforms, vol. 13 (1988), pp. 697-705.

(3) Martín, L., Bello, M. A., Martín, A.: "Accelerated alteration test on the stones used in Catedral of Granada (Spain)." Proceed. VII Int. Symp. On Deterioration and Conservation of Stone, Lisboa (1992), vol. 1, pp. 845-850.

(4) McMahon, D. J., Sandberg, P., Folliard, K., Mehta, P. K.: "Deterioration mechanisms of sodium sulphate." Proceed. VII Int. Symp. On Deterioration and Conservation of Stone, Lisboa (1992), vol. 2, pp. 705-714.

(5) Binda, L., Baronio, G., Squarcina, T.: "Evaluation of the durability of bricks and stones and of conservation treatments". Proceed. VII Intern. Symp. On Deterioration and Conservation of Stone, Lisboa (1992), vol. 2, pp. 753-762.

(6) Grossi, C. M.: "Cristalización de sales en rocas monumentales porosas y auscultación mediante emisión acústica". p. 261. Tesis doctoral. Dpto. Geología. Universidad de Oviedo, (1992).

(7) Pérez, A., Ordaz, J., Esbert, R., Alonso, F .J.: "Microfissuring evolution of Axeitos granite along a crystallization test." Proceed. II Intern. Symp. Conservation of Monuments in the Mediterranean Basin, Venecia (1994), pp. 115-119.

(8) Íñigo, A. C., Vicente-Tavera, S., Rives, V.: " Statistical desing applied to hydric property behaviour for monitoring granite consolidation and water-repellency treatments" Mater. Construcc. Vol. 56, n² 281 (2006), pp. 19-30.

(9) Alonso, F. J., Esbert, R., Ordaz, J.: "Saline spray action on treated dolomitic stone". Proceed. II Intern. Symp. Conservation of Monuments in the Mediterranean Basin, Venecia (1994), pp. 867-870.

(10) Ferreira, A.P., Delgado, J., Costa, D.: "Behaviour of water repellents in granites under accelerated ageing test." Proceed. II Int. Symp. Conservation of Monuments in the Mediterranean Basin, Venecia (1994), pp. 877-882.

(11) Casal, M., Silva, B., Delgado, J.: "Agents and forms of weathering in granitic rocks used in monuments". Proceed of European Symposium Science Technology and European Cultural Heritage, Bolonia (1989), pp. 439-442.

(12) Rivas, T.: "Mecanismos de alteración de rocas graníticas utilizadas en la construcción de edificios antiguos de Galicia". p. 358, Servicio de Publicaciones e Intercambio Científico de la Univ. Santiago de Compostela, (1997).

(13) Silva, B,. Rivas, T., Prieto, B.: "Soluble Salts in Granitic Monuments: Origin and Decay Effects". En: Applied Study of Cultural Heritage and Clays (2003), pp. 113-131.

(14) Birginie, J. M., Rivas, T., Prieto, B., Auger, F.: "Comparaison de l'altérabilité au brouillard salin de deux pierres calcaires de construction au moyen de mesures pondérales, acoustiques et par traitement d'images ". Mater. Construcc., vol. 50, n 259, (2000), pp. 27-43. 
(15) Rivas, T., Prieto, B., Silva, B., Birginie, J. M.: "Comparison between traditional and chamber accelerated ageing test on granitic rocks". Proceed. 9th Intern. Congress on deterioration and Conservation of Stone, Venecia (2000), pp. 171-180.

(16) Rivas, T., Birginie, J. M., Prieto, B., Auger, F.: "Granite decay by a marine salt-spray accelerated ageing test". En: Protection and Conservation of the Cultural Heritage of the Mediterranean Cities. (2002), pp. 227-233.

(17) Cardell, C., Rivas, T., Mosquera, M. J., Prieto, B., Birginie, J. M., Silva, B., Moropoulou, A., Van Grieken,.R.: "Patterns of damage in igneous and sedimentary rocks under conditions simulating sea-salt weathering". Earth Surf. Process. Landforms, n 28, (2003), pp. 1-14.

(18) Reunion Internationale des Laboratoires d'Essais et de recherche sur les materiaux et les Constructions. (RILEM). "Crystallization test by total inmersion (Test V.1.) Crystallization test by partial inmersion (Test V. 2.)". Proceed. Intern. Symposium Deterioration and Conservation of Stone monuments. UNESCO-RILEM, Paris (1978).

(19) Rivas, T., Prieto, B., Silva, B.: "Influence of rift and bedding planes on the physico-mechanical properties of granitic rocks. Implications for the deterioration of granitic monuments". Building and Environment no 35 (2000), pp. 387-396.

(20) Rivas, T., Prieto, B., Silva, B.: "Permeability to water vapour of granitic rocks: application to the study of deleterious effects of conservation treatments". Building and Environment, no 36 (2001), pp. 239-346.

(21) Rivas, T., Prieto, B., Silva, B.: "The effect of crystallisation of Na2So4 and Na Cl on the weathering of various granites." Proceed. 4 Intern. Symp. on the conservation of monuments in the Mediterranean Basin, Rhodes (1997), vol. 1, pp. 271-281.

(22) Rivas, T., Prieto, B., Silva, B., Birginie, J. M.: "Weathering of granitic rocks by chlorides: effects of the nature of the solution on weathering morphology". Earth Surf. Process. Landforms, no 28 (2003), pp. 425-436.

(23) Rivas, T., Prieto, B., Silva, B.: "Gypsum formation in granitic rocks by dry deposition of sulphur dioxide." Proceed. 4 Intern. Symp. on the conservation of monuments in the Mediterranean Basin, Rhodes (1997), vol. 1, pp. 263-270.

(24) Rivas, T., Silva, B., Prieto, B.: "Medida de la durabilidad de dos tratamientos de hidrofugación aplicados a rocas graníticas". Mater. Construcc., Vol. 48, T. no 250 (1998), pp. 5-14.

(25) Silva, B., Rivas, T., Prieto, B.: "Tratamientos de consolidación e hidrofugación aplicados en sustratos graníticos húmedos y contaminados por sales". Mater. Construcc., Vol. 50, no 257, (2000), pp. 15-31. 